2018 TheoLogica

An International Journal for Philosophy of Religion and Philosophical Theology

S.I. NEW THEMES IN ANALYTIC DOGMATIC THEOLOGY

DOI: https://doi.org/10.14428/thl.v0i0.1303

\title{
Original Sin, the Fall, and Epistemic Self-Trust
}

\author{
JONATHAN C. RUTLEDGE \\ University of St Andrews \\ jr229@st-andrews.ac.uk
}

\begin{abstract}
In this paper, I argue that no strong doctrine of the Fall can undermine the propriety of epistemic self-trust. My argument proceeds by introducing a common type of philosophical methodology, known as reflective equilibrium. After a brief exposition of the method, I introduce a puzzle for someone engaged in the project of self-reflection after gaining a reason to distrust their epistemic selves on the basis of a construal of a doctrine of the Fall. I close by introducing the worry as a formal argument and demonstrate the self-undermining nature of such an argument.
\end{abstract}

Keywords: Analytic Theology, Epistemic Self-trust, the Fall, Noetic Effects of Sin, Original Sin

In this paper, I highlight a tension between a common methodology in philosophical inquiry and some construals of the doctrine of the Fall. I then present an argument from an extreme interpretation of the doctrine of the Fall to the conclusion that no human person ought to trust their cognitive faculties. ${ }^{1}$ After setting up this argument, I demonstrate that even in this worst-case scenario of the implications of the doctrine of the Fall for our reliability as cognitive agents-namely, that we are woefully unreliable when it comes to grasping truth ${ }^{2}$ - human agents do not have good reason to distrust their epistemic selves. That is, I argue that no strong doctrine of the Fall can undermine the propriety of epistemic self-trust or trusting one's epistemic intuitions. ${ }^{3}$

${ }^{1}$ It's possible for us to limit the interpretation of the Fall to only affect knowledge (cf. Owen 1965 248); referenced in McMartin $(2016,354)$, as opposed to other epistemic goods such as rationality or practical wisdom, or only our grasp of godly things rather than practical affairs (cf. Gerrish 1962 12); also quoted in McMartin 2016, 354). However, for the sake of my argument, the more extreme views are of the greatest interest.

2 And lest we think such a claim entirely lacks any scriptural support, consider Ephesians 4:17-18 (NRSV): "Now this I affirm and insist on in the Lord: you must no longer live as the Gentiles live, in the futility of their minds. They are darkened in their understanding, alienated from the life of God because of their ignorance and hardness of heart." See also much of Romans 1, Ephesians 2, 2 Corinthians 4:3-4, the constant gospel (and prophetic) theme that many people lack ears to hear and eyes to see (e.g. Isaiah 6).

${ }^{3}$ Notice that this thesis is consistent with the view that we should not trust our epistemic intuitions for some other reason. It's just that no reason for doubting our reliability can be gained from reflections on the 
Such an argument is needed, especially in light of the hope for increased dialogue between the disciplines of scriptural scholarship, theology, and analytic philosophy. It is commonplace, for instance, for these various practitioners to present moral intuitions in support of rejecting certain readings of a passage of scripture (e.g. genocide passages found in the Hebrew Scriptures). Yet often, when presenting such intuitions, theologians and philosophers are confronted with a doctrine of the Fall as an insurmountable objection to trusting their intuitions in a particular case. ${ }^{4}$ Indeed, they might be accused of shaping God to fit the image of man by appealing to their moral intuitions over and against the plain reading of the scriptural text. ${ }^{5}$ My point in this paper is that even if the objector is right to think that our cognitive capacities are completely destroyed by the Fall, they are wrong to think that calls our moral intuitions into question for us thereby undermining the relevance of those intuitions to our assessments of scripture. In other words, it will not follow that it is wrong, epistemically speaking, to trust our moral intuitions in such cases.

I proceed as follows. In $\S 1$ I present my preferred methodology for theological inquiry; namely, reflective equilibrium. My reason for so beginning is to provide a working model of a standard method of inquiry that is assumed as permissible within most academic settings but which, nevertheless, is susceptible to the central argument with which I shall be concerned. Then in \$2 I present a worst-case scenario interpretation of the doctrine of the Fall founded upon the Genesis text and some of John Calvin's reflections on the Fall in his Institutes of the Christian Religion. On the basis of this Calvin-inspired interpretation of the doctrine of the Fall, I then put together an argument concerning the reliability of post-lapsarian human cognition. The resulting argument, if it were successful, would undermine trusting one's intuitions concerning any and all matters of inquiry, thus undercutting the common practice of reflective equilibrium, which assumes that trust in one's cognitive faculties is rational. However, in the second half of \$2 I demonstrate the self-undermining nature of any such argument. Thus, I conclude that epistemic self-trust and trusting one's intuitions cannot be undermined by any argument proceeding from a strong doctrine of the Fall.

Fall and original sin. It is also consistent with an agent choosing to recalibrate the evidential weight they assign alternative interpretations of, say, scripture as opposed to their own intuitions in a given case. But the very act of recalibrating the evidential weightings involved presupposes epistemic self-trust.

${ }^{4}$ Indeed, this has happened to me on more than one occasion.

${ }^{5}$ I don't assume that there is such a thing as "the plain reading of the scriptural text" for the purposes of this paper. Indeed, I think the argument here goes through without becoming encumbered by questions of divine inspiration of scripture or questions of inerrancy and infallibility. 


\section{On Reflective Equilibrium}

In philosophy, it is quite common to engage in a methodology known as reflective equilibrium. ${ }^{6}$ This method is most easily understood when one asks oneself what should be privileged, either one's theories or the data (or intuitions) the theories are meant to explain, when engaged in a particular domain of inquiry. Let us use ethics as an illustration.

Suppose you are trying to select an ethical theory according to which you will order your life, and suppose for simplicity's sake that you are only considering utilitarianism ${ }^{7}$ and Kantian deontology, with the second formulation of the categorical imperative as your primary guide (i.e., to always treat others as ends in themselves, and not merely as means). ${ }^{8}$ Further suppose that you consider whether it would be right to frame an innocent person for a crime that would eventuate in their death at your hands. And suppose further that this action would be guaranteed to set the minds of your populace at ease and prevent riots that would certainly result in at least 20 deaths of innocent persons were they to occur. The utilitarian theory, on the one hand, tells you that you should surely bring about this state of affairs on the assumption that it results in the greatest overall balance of good for the greatest number. Kantian deontology, on the other hand, would categorically rule out such an action since to murder an innocent person to achieve some end would surely be an instance of treating that person as a mere means and not also an end in themselves.

But suppose now that after determining the deliverances of utilitarianism and Kantian deontology for this act you consult your own intuitions, i.e. your moral data, about the case. The idea of punishing an innocent person seems to you as always morally unjustified, even if it leads to exceedingly positive consequences. Thus, you find yourself with an intuition that conflicts with the truth of utilitarianism. What is the proper procedure from here?

Well, reflective equilibrium is the process of modifying one's intuitions and one's theories in light of each other, such that one is able to arrive at some degree of coherence between them. ${ }^{9}$ In other words, reflective equilibrium is a permissive method of rational inquiry whereby two individuals might reasonably come to different conclusions about

${ }^{6}$ 'Reflective equilibrium' can also refer to a state at which this method is aimed. The following article, in its introduction, draws explicit attention to this ambiguity of 'reflective equilibrium': (Daniels 2016).

${ }^{7}$ See John Stuart Mill (1979), and the now indispensable debate: Utilitarianism: For and against (Smart and Williams 1973).

8 "The subject of ends (i.e. the rational being itself) must be made the basis of every maxim of action and thus be treated never as a mere means but as the supreme limiting condition in the use of all means i.e. also as an end" (Immanuel Kant 2008, 35).

${ }^{9}$ A Theory of Justice (Rawls 1999) is the work in which this method of reflective equilibrium was coined. It was originally published in 1971. 
the same subject matter without one of them giving up their claim to rationality. For instance, person A might trust her intuitions regarding the moral wrongness of killing an innocent person more than she trusts Utilitarianism and thereby reasonably reject it in favor of a deontological approach to ethics. However, person B might, when faced with the same decision, find that she trusts Utilitarianism more than she trusts her ability to track the rightness or wrongness of particular acts, in which case, she might reasonably dismiss her intuition as misleading and endorse the utilitarian verdict. And according to the method of reflective equilibrium, both verdicts could be rational relative to the individual drawing each respective verdict.

Now whether or not reflective equilibrium is a promising method of philosophical inquiry, it assumes something important about the nature of inquiry; namely, that inquiry requires an inquirer that can sort through the theories and the data. Moreover, the method assumes that there is nothing suspicious in assigning such a place of epistemic importance to human cognitive faculties and their deliverances. After all, it is the judgments of the inquirer concerning her intuitions and their relationship to the theories she considers that are decisive in determining which position(s) she ought to affirm.

In pure philosophical inquiry, such a view need not be highly problematic. Yet, as soon as one admits of certain theological premises, grounds appear that threaten our confidence in the deliverances of human cognitive faculties. Indeed, the doctrine of the Fall has been historically interpreted by some theologians in such a way that it seriously threatens to undermine epistemic trust in oneself and others. Let us, then, turn to a discussion of the imago dei in Christian theology and the potential cognitive damage to which the imago dei is allegedly subject as a result of the Fall.

\section{Original Sin and Our Cognitive Capacities}

The creation of humanity in Genesis 1 affirms quite clearly that humanity is made in the image of God:

"26 Then God said, "Let us make humankind in our image, according to our likeness; and let them have dominion over the fish of the sea, and over the birds of the air, and over the cattle, and over all the wild animals of the earth, and over every creeping thing that creeps upon the earth."

${ }^{27}$ So God created humankind in his image,

in the image of God he created them;

male and female he created them. ${ }^{\prime \prime}$

${ }^{10}$ Unless otherwise indicated, Biblical references will be to the NRSV. 
What constitutes the image of God ${ }^{11}$, as it is understood in Genesis, has been fairly controversial historically. Some theologians claim that the image of God in humanity is constituted by certain capacities humans share with the divine ${ }^{12}$, capacities which are presumably lacked to some significant degree by other creatures (e.g. rationality, imagination, or an ability to lovingly respond to $\left.\operatorname{God}^{13}\right)$. Although it seems unlikely that such a view of the image of God quite reflects the original understanding of the Genesis text ${ }^{14}$; nevertheless, at least the potential for the possession of certain intellectual capacities is, in some important way, related to human possession or implementation of the image of God.

Emphasizing human cognitive capacities as part (or necessary concomitants) of the image of God is especially important if we are to determine the extent to which we can trust those cognitive capacities in our post-lapsarian context. After all, in the biblical narrative, it is the image of God that is in some sense marred or effaced following the Fall caused by the primal human sin. Consider, then, the following enlightening passage from John Calvin:

"Original sin...may be defined as the hereditary corruption and depravity of our nature. This reaches every part of the soul, makes us abhorrent to God's wrath and produces in us what Scripture calls works of the flesh...Our nature is not only completely empty of goodness, but so full of every kind of wrong that it is always active. Those who call it lust use an apt word, provided it is also stated...that everything which is in man, from the intellect to the will, from the soul to the body, is defiled and imbued with this lust. To put it briefly, the whole man is in himself nothing but lust." 15

\footnotetext{
${ }^{11}$ I thank Christa McKirland for her paper presentation, "The Image of God and Intersex Persons," for the Logos Institute of Analytic and Exegetical Theology on October 13, 2016. The presentation of her research was extremely helpful for my thinking on this subject matter. See also (Crisp 2016, 51-70) i.e. chapter 4, "The Christological Doctrine of the Image of God") for an excellent discussion of the issues.

12 Proponents of such a view include: (i) Irenaeus, Against Heresies (2015); (ii) Aquinas, Summa Theologiae Ia q. 93 a. 4 \& 6; (iii) John Calvin, The Institutes of the Christian Religion (1986), 1.15; (iv) The Catechism of the Catholic Church III.I.1, art. 1; and (v) J. P. Moreland, The Recalcitrant Imago Dei: Human Persons and the Failure of Naturalism (2009).

${ }^{13}$ Here I have in mind Emil Brunner (1952, 55-61; 75-78).

14 That understanding, I take it, would be much closer to understanding humans as representatives of God to creation. That is, humanity exercises dominion as deputized authorities over creation. For variations on this theme, see: (i) Plantinga, Thompson, Lundberg (2010, 182-5) ; (ii) Walton (2015, 190-197); and (iii) Wright (2008).

${ }^{15}$ Calvin, Institutes, 2.1.8, 90-1. As I admit in the text, Calvin is not altogether clear concerning his approach to the image of God post-Fall. On the one hand, in the passage quoted and in some other points of discussion concerning the post-lapsarian image of God, it seems that the image of God has been entirely effaced; that is, nothing good remains. In other places, Calvin offers a less pessimistic position that merely claims the image is severely damaged. I think the latter interpretation is preferable on grounds of interpretive charity. Nevertheless, I assume the extreme view above for the sake of developing a worst-case scenario for the purposes of argument.
} 
According to Calvin, all humanity has inherited a sort of disease known as original sin. As he describes this malady, every part of the soul, including both the intellect and will is 'defiled' and 'completely empty of goodness'. This language concerning the problem of sin is strong indeed, and it might lead us to wonder whether or not an intellect that fits such a description is worthy of the high epistemic status attributed to it by those who engage in the method of reflective equilibrium. On such a view, it is claimed that we can consult our intuitions-i.e., the deliverances of our cognitive capacities and perhaps rely on them in determining what to believe about various domains of inquiry including ethical theory or even the nature of scriptural hermeneutics. But suppose that Calvin is right and that original sin has afflicted our intellects as to make them in fact unreliable. Not only unreliable, however, but completely empty of goodness, which includes epistemic goodness of all sorts. What would this imply about the epistemic propriety of trusting the deliverances of our cognitive faculties?

Perhaps contrary to expectations, very little is implied. Or at least, very little is implied for anyone trying to reason through these puzzling questions from the inescapable first-person perspective (i.e. "the egocentric predicament"16) in which human agents find themselves. To understand why we should not be bothered by the potential implications of the doctrine of the Fall for our epistemic practices, consider the following bit of reasoning an agent might discern; that is, an agent who comes to believe that there is a real possibility that her cognitive faculties are unreliable due to the debilitating noetic effects of sin:

"Sally has always trusted herself generally when it comes to her intellectual activities. That is, she has always considered herself generally (though not infallibly) trustworthy concerning the gathering of evidence and the evaluation of that evidence. However, upon reading John Calvin's Institutes, she comes to believe that there is a real possibility that her intellectual activities are in some significant way unreliable due to the corruption of $\sin$. As a result, she acquires a reason to doubt that her cognitive faculties are generally reliable. This is an unfortunate thing, for now Sally is unsure whether or not she can trust the particular deliverances of her intellectual activities in the future. And what's worse, it seems that the reason Sally has for distrusting her intellectual self in general is a reason she only gains by way of an act of trusting those very cognitive capacities being called into question. That is, she gains a reason for ceasing to trust her epistemic self with an act of trusting her epistemic self. Puzzled about the implications for her cognitive life, Sally wonders how to move forward."17

\footnotetext{
16 This label was coined by Richard Foley (1987).

17 To engage in a discussion of the importance and justification of epistemic self-trust would take us too far afield in this paper. For those interested to learn more, see (i) Foley (2001) and (ii) Zagzebski (2012).
} 
Perhaps this thought experiment seems a bit misleading as an interpretation of Calvin, but let us leave proper interpretation aside. For the interpretation I have suggested is a worst-case scenario understanding of the Fall, and if it can be shown that there is room for Sally to trust her epistemic faculties in a worst-case scenario, then it will plausibly follow that in any better-case scenario she again will be within her epistemic rights to trust her intellectual activities. So let us consider the implications of this thought process for Sally. ${ }^{18}$

There are a couple of features of this situation that merit our attention. First, when Sally considers the noetic effects of sin, she acquires a reason to doubt her reliability as an epistemic agent. However, as a matter of practical necessity, she also begins her journey to this realization with a presumption of her epistemic reliability. In other words, Sally begins with a self-given and pre-reflective reason to think the she is a reliable epistemic agent. Thus, upon reading Calvin, Sally finds herself with both a reason to affirm and a reason to doubt her reliability as an epistemic agent; that is, there is a clash of reasons concerning her reliability, a clash which must be sorted out.

But now, who will be doing the sorting? There is no other party to which Sally might turn to decide which reason, either the one for or the one against her reliability as an epistemic agent, bears the most weight. So obviously, it is Sally who must sort out the tension concerning whether to continue trusting her epistemic self, and she must do so egocentrically. But then let us draw out the possible ways of resolving Sally's conundrum.

First, Sally can decide to simply continue trusting the deliverances of her epistemic faculties. Now perhaps contrary to appearances, this continuation of trust need not be one of brazen disregard concerning the effects of sin. Sally has clearly been deeply troubled when reflecting on the reach of original sin after the Fall. However, after long and sober reflection, she may simply find that it just seems best to her that she continue to trust herself. Indeed, Sally may even recalibrate the degree of reliability she assigns to her cognitive faculties in hopes that she may adequately account for the presence of sin without giving up trust in her epistemic self on the whole.

However, it is also possible for Sally to cease trusting her epistemic self, or at least, such a position seems possible in the abstract. But how might this go, exactly? Is there a clear path of reasoning that might coherently lead Sally to this conclusion? Perhaps it is possible for Sally to just adopt such a stance by fiat ${ }^{19}$, but suppose instead that she tries to reason her way to distrusting her cognitive faculties. The following argument seems to articulate well the line of reasoning Sally might have in mind:

${ }^{18}$ I hope it's obvious that Sally is meant to be representative of the epistemic conundrum facing anyone in similar circumstances.

19 Although, it's hard to imagine how we might truly call such a move rational. If one adopts an attitude of distrust towards oneself by fiat (i.e., without even considering a reason to adopt the attitude), the move seems non-rational at best. 
i. If Calvin's understanding of original sin is correct, then my epistemic activities are not trustworthy.

ii. Calvin's understanding of original sin is correct.

iii. My epistemic activities are not trustworthy.

Now, consider whether this string of reasoning, which led Sally to a reason to doubt her rationality, can itself be rationally endorsed. On the one hand, if the answer is yes (i.e. that the line of reasoning can be endorsed by Sally), then the same line of reasoning will lead to two inconsistent propositions: (a) Sally is epistemically trustworthy, i.e. with respect to following the lines of this argument, and (b) Sally is not epistemically trustworthy. But of course, from this it follows that Sally both is and is not epistemically trustworthy, and no string of reasoning that leads to a contradiction is either trustworthy or rationally endorsable.

Suppose instead that the answer is no (i.e. that the line of reasoning above cannot be endorsed by Sally). Well, if the reasoning itself cannot be reasonably endorsed, then why would Sally trust the conclusion to which the reasoning leads? Surely that would be foolhardy, for even if the conclusion were true, Sally could have no reason to believe it to be true!

In summary then, the above argument can be clearly seen to be self-undermining. For if the conclusion is true, then no one can rationally endorse the argument, and if the conclusion is false, then no one should rationally endorse the argument. Thus, it seems that there is simply no road open to a rational endorsement of the above argument. And as a result, the best way forward for Sally is to continue trusting her epistemic self, even in the face of the worries of original $\sin .{ }^{20}$

\footnotetext{
${ }^{20}$ The results here are similar to the results one might expect when dealing with the new evil demon problem: suppose that there are two possible worlds, $w_{1}$ and $w_{2}$, the first of which is the actual world in which all epistemic agents undergo experiences in normal ways (i.e. by seeing chairs and tasting ice cream, let's say) and the second of which is an evil demon world (i.e. a world in which all experience is misleading, such that one never sees chairs or tastes ice cream, but rather, is simply given the illusion that one is doing so). Suppose the denizens of $w_{2}$ are informed of the possibility that they exist in this elaborate demon world. What should they do epistemically? My view is that this possibility has basically no implications for the denizens of $w_{2}$, despite the fact that they are systematically deceived and mislead. For discussion of such a case in favor of evidentialism and against reliabilism, see (Conee and Feldman 2004, 83-100). For a defense of the sort of epistemological framework within which I stand, see (Jonathan Kvanvig 2014). For various theological applications of such an epistemological framework, see (i) "An Epistemological Corrective to Doctrines of Assurance," (Rutledge 2017, 163-177) and (ii) "Commonsense, Skeptical Theism, and Different Sorts of Closure of Inquiry Defeat" (Rutledge 2017, 17-32).
} 


\section{Conclusion}

I have argued that the doctrines of original sin and the Fall, contrary to initial appearances, have no implication that we should not trust our cognitive faculties. Indeed, I have argued that this is the case even if in fact the Fall has rendered our cognitive faculties completely and utterly unreliable when it comes to finding the truth.

Of course, theologians and philosophers alike ought to recognize that a degree of fallibility resides within all of their intuitions, moral and otherwise, and surely it is unproblematic to admit this. ${ }^{21}$ Indeed, remembering that we continue to suffer from the effects of the fall (even post-conversion ${ }^{22}$ ) might give us a reason to pause and ensure that our intuitions concerning various matters are not being swayed by non-epistemic concerns. However, it is likewise important that admissions of fallibility not be pressed to the point that intuitions are wholly dismissed as irrelevant. Perhaps some scholar might wish to find sources within theology to motivate the complete dismissal of the intuitions of her colleague; however, as should be clear, the doctrine of the Fall and original sin will be of no use to that end..$^{23}$

\section{Bibliography}

Aquinas, Thomas. 2009. The Summa Theologiae Of St. Thomas Aquinas: Latin-English Edition, Prima Pars, Q. 1-64. Scotts Valley, CA: NovAntiqua.

Brunner, Emile. 1952. Dogmatics, II: The Christian Doctrine of Creation and Redemption. Translated by O. Wyon. Philadelphia: Westminster.

Calvin, John. 1986. The Institutes of the Christian Religion. (T. Lane, \& H. Osborne, Eds.) Grand Rapids, MI: Baker Book House.

Catechism of the Catholic Church. 2003.

http://www.vatican.va/archive/ENG0015/ INDEX.HTM. Accessed July 28, 2017.

${ }^{21}$ An anonymous reviewer emphasized the importance of the assumption, for my argument, that we are at the limit of the function of our rational capacities. But if we relax this assumption, then there is nothing wrong with our deferring to an external source in acquiring beliefs, such as deferring to a reading of scripture in order to adopt a moral belief. Lest I be misunderstood, then, notice that the point of my argument is to show that in any scenario, either at the limit of our rational capacities or when such an assumption is relaxed, epistemic self-trust in our intuitions is permissible. I do not claim that when sorting through the data of our intuitions and data from other sources, we might not choose to defer to the other sources. The choice to defer (or demur or whatever) is nevertheless again an act that presupposes epistemic self-trust, and so, it is confirmation rather than disconfirmation of the position argued here.

22 (McMartin 2016, 359-360).

${ }_{23}$ Many thanks to the comments of two anonymous referees who forced me to slow down and think much more carefully through the various steps in the argument of this paper. It is much improved due to their generous contributions. 
Conee, Earl and Richard Feldman. 2004. "Evidentialism." In Evidentialism: Essays in Epistemology, edited by Earl Conee and Richard Feldman, 83-100. Oxford: Oxford University Press.

Crisp, Oliver D. 2016. The Word Enfleshed. Grand Rapids: Baker Academic.

Daniels, Norman. 2016. "Reflective Equilibrium." In The Stanford Encyclopedia of Philosophy, edited by Edward N. Zalta. https://plato.stanford.edu/archives/win2016/entries/reflective-equilibrium.

Foley, Richard. 1987. The Theory of Epistemic Rationality. Cambridge, MA: Harvard University Press.

Foley, Richard. 2001. Trust in Oneself and Others. Cambridge: Cambridge University Press.

Gerrish, B. A. 1962. Grace and Reason: A Study in the Theology of Luther. Oxford: Clarendon Press.

Irenaeus. 2015. Against Heresies. Beloved Publishing.

Kant, Immanuel. 2008. The Groundwork of the Metaphysics of Morals. Translated by Jonathan Bennett. http://earlymoderntexts.com/assets/pdfs/kant1785.pdf

Kvanvig, Jonathan L. 2014. Rationality and Reflection: How to Think About What to Think. Oxford: Oxford University Press.

McKirland, Christa L. October 2016. "The Image of God and Intersex Persons," Paper presented at the Logos Institute for Analytic and Exegetical Theology, St. Mary's School of Divinity.

McMartin, Jason. 2016. "Reason." In TET Clark Companion to the Doctrine of Sin, edited by Keith L. Johnson and David Lauber, 351-367. London: Bloomsbury T\&T Clark.

Mill, J. S. Utilitarianism (G. Sher, Ed.). Indianapolis: Hackett, 1979.

Moreland, J. P. 2009. The Recalcitrant Imago Dei: Human Persons and the Failure of Naturalism. London: SCM.

Owen, John. 1965. The Holy Spirit. Carlisle, PA: Banner of Truth Trust.

Plantinga, R. J., Thompson, T. R., and Lundberg, M. D. 2010. An Introduction to Christian Theology. Cambridge: Cambridge University Press.

Rawls, John. 1999. A Theory of Justice, 2nd Edition. Cambridge, MA: Harvard University Press.

Rutledge, Jonathan Curtis. 2017. "An Epistemological Corrective to Doctrines of Assurance." European Journal for Philosophy of Religion 9 (1): 163-177.

Rutledge, Jonathan Curtis. 2017. "Commonsense, Skeptical Theism, and Different Sorts of Closure of Inquiry Defeat." Faith and Philosophy 34, no. 1 (January): 17-32.

Smart, J. J. C., and Bernard Williams. 1973. Utilitarianism: For and Against. Cambridge: Cambridge University Press.

Walton, John H. 2015. The Lost World of Adam and Eve. Downers Grove, IL: InterVarsity Press. 


\section{ORIGINAL SIN, THE FALL, AND EPISTEMIC SELF-TRUST}

Wright, N. T. 2008. Surprised by Hope: Rethinking Heaven, the Resurrection, and the Mission of the Church. New York, NY: HarperOne.

Zagzebski, Linda T. 2012. Epistemic Authority: A Theory of Trust, Authority, and Autonomy in Belief. Oxford: Oxford University Press. 